\title{
Reflexiones sobre el
}

derecho fundamental a

la buena Administración

pública en el derecho

administrativo brasilero

\author{
Daniel Wunder Hachem ${ }^{1}$ \\ Diana Carolina Valencia Tello ${ }^{2}$
}

\section{RESUMEN}

El derecho fundamental a la buena Administración pública, desde su inserción en la Carta de Derechos Fundamentales de la Unión Europea, pasó a ser incorporado en distintos ordenamientos jurídicos. Este trabajo tiene como objetivo explicar sus orígenes, contenido jurídico y contribuciones para el

1 Profesor de Derecho Constitucional y Derecho Administrativo de la Pontificia Universidad Católica del Paraná y de la Universidad Federal del Paraná, Paraná, Brasil. Doctorado y maestría en Derecho de la Universidad Federal del Paraná. Posdoctorado de la Université Paris 1, Panthéon-Sorbonne, París, Francia. Director de Publicaciones de la Red Docente Eurolatinoamericana de Derecho Administrativo. Director del NUPED - Núcleo de Pesquisas em Políticas Públicas e Desenvolvimento Humano de la PUCPR. Abogado. Correo-e: daniel.hachem@pucpr.br. Enlace ORCID: http://orcid.org/0000-0001-8519-8420.

2 Profesora principal de Derecho Administrativo de la Universidad del Rosario, Bogotá, Colombia. Especialista en Derecho Administrativo y Derecho Ambiental de la Universidad del Rosario, Bogotá, Colombia. Maestría, doctorado y posdoctorado de la Universidad Federal del Paraná, Paraná, Brasil. Se ha desempeñado como subdirectora administrativa del Ministerio de Agricultura y Desarrollo Rural, coordinadora del Fondo de Paz - Presidencia de la República de Colombia y abogada del Departamento Administrativo de la Función Pública. Correo-e: dianac.valencia@urosario.edu.co. Enlace ORCID: http://orcid.org/00000001-5936-6005. Fecha de recepción: 5 de agosto de 2018. Fecha de modificación: 30 de agosto de 2018. Fecha de aceptación: 24 de septiembre de 2018. Para citar el artículo: Wunder Hachem, Daniel, Valencia-Tello, Diana Carolina, "Reflexiones sobre el derecho fundamental a la buena administración pública en el derecho administrativo brasilero", Revista digital de Derecho Administrativo, Universidad Externado de Colombia, n. ${ }^{\circ} 21,2019$, pp. 47-75. DOI: https://doi.org/10.18601/21452946.n21.05 
derecho administrativo, y su recepción por el derecho brasilero. La investigación encuentra que, pese a que el artículo 41 de la Carta de Niza no contiene un desarrollo novedoso sino una consolidación de derechos ya reconocidos doctrinaria y jurisprudencialmente, el reconocimiento de ese derecho tiene un valor simbólico importante para el derecho administrativo, por colocar en el centro de esta disciplina jurídica el ser humano y la protección de su dignidad.

Palabras clave: derechos fundamentales, buena Administración pública, dignidad de la persona, Carta de Derechos Fundamentales de la Unión Europea, derecho administrativo brasileño.

\section{Reflections on the Fundamental Right to Good Public Administration in Brazilian Administrative Law}

\section{ABSTRACT}

The fundamental right to good public administration has been integrated in different legal systems, since its recognition in the European Charter on Fundamental Rights. This work aims to explain its origins, legal content and contributions to Administrative Law, with particular regards to its reception by the Brazilian legal system. The research shows that article 41 of the Charter of Nice does not constitute a new development, but rather a consolidation of rights already recognized in judicial decisions and scholarly works. The recognition of the right to good public administration has a significant symbolic value for Administrative Law, as it places at the center of this legal discipline the individual and the special protection of its dignity.

Keywords: Fundamental Rights, Good Public Administration, Dignity of the Individual, European Union Charter on Fundamental Rights, Brazilian Administrative Law.

\section{INTRODUCCIÓN}

El derecho fundamental a la buena Administración pública nació en el ambiente del derecho comunitario europeo y fue posteriormente perfeccionado y robustecido por el derecho administrativo iberoamericano. Como será analizado a lo largo del presente artículo, este derecho fue establecido en la Carta de Derechos Fundamentales de la Unión Europea en el año 2000 y, posteriormente, fue desarrollado de forma más amplia por la Carta Iberoamericana de Derechos y Deberes del Ciudadano en relación con la Administración pública, de 2013. La redacción de esta carta fue confiada por el Consejo Directivo 
del Centro Latinoamericano de Administración para el Desarrollo (CLAD) al profesor Jaime Rodríguez-Arana Muñoz ${ }^{3}$.

A simple vista, el derecho a la buena Administración pública no representa nada nuevo, pues, en teoría, todos los ordenamientos jurídicos han definido diversos derechos para garantizar el buen desempeño de la Administración pública. Pero en el siglo XXI, el derecho a la buena Administración adquiere nuevas connotaciones, en razón a la necesidad de fortalecer los procesos democráticos en todos los Estados, mejorando la participación de la ciudadanía y la rendición de cuentas ${ }^{4}$, junto a la protección de los derechos fundamentales de todos los individuos. En este sentido, la finalidad principal de este nuevo "derecho síntesis" es ampliar la protección del ciudadano en relación con los poderes públicos, en todos los Estados constitucionales y democráticos de derecho.

En consecuencia, el derecho a la buena Administración pública busca agrupar todo el conjunto de derechos que tienen los ciudadanos frente a las Administraciones públicas, con el objetivo de garantizar el pleno goce de los derechos fundamentales $y$, al mismo tiempo, reinterpretar las potestades de los poderes públicos dentro de las democracias constitucionales.

Así, el presente artículo busca resaltar la importancia de este derecho para la consolidación de Estados constitucionales y democráticos de derecho ${ }^{5}$ mediante cuestionamientos tales como: ¿por qué es importante el derecho fundamental a la buena Administración pública?, ¿cómo fue creado dicho derecho?, ¿cuándo se tornó exigible?, y ¿qué tipo de cambios introduce en las Administraciones públicas? Para dar respuestas a estos interrogantes, en la primera sección, el estudio analizará los orígenes del derecho fundamental a la buena Administración pública, para después, en la segunda sección, delimitar su contenido jurídico, sus potencialidades y las contribuciones que dicho derecho aporta al derecho administrativo. Finalmente, la tercera sección se dedicará a examinar en concreto cómo se materializa el derecho a la buena Administración pública en el caso brasilero, para después realizar algunas consideraciones finales.

3 La Administración al Día, "El catedrático Rodríguez-Arana redactará la Carta de Derechos Ciudadanos de Iberoamérica", Madrid: Instituto Nacional de Administración Pública, 2013. Disponible en línea http://laadministracionaldia.inap.es/noticia.asp?id=1500246 [consultado el 5 de agosto de 2018].

4 Adriana da Costa Ricardo Schier y Juliane Andrea de Mendes Hey Melo, "O direito à participação popular como expressão do Estado Social e Democrático de Direito", $A_{\&} C$ Revista de Direito Administrativo \& Constitucional, n. ${ }^{\circ}$ 69, Belo Horizonte: Instituto de Direito Romeu Felipe Bacellar, 2017, pp. 127-147.

5 Sobre dicho concepto, véase: JuAn Gustavo Corvalán, "Los ejes centrales de la división de poderes en el Estado constitucional de derecho", Revista de Investigações Constitucionais, vol. 2, n. ${ }^{\circ}$ 1, Curitiba: Capes, 2015, pp. 225-256; y "Soberanía y Estado constitucional", A\&C - Revista de Direito Administrativo \& Constitucional, n. ${ }^{\circ} 62$, Belo Horizonte: Instituto de Direito Romeu Felipe Bacellar, 2015, pp. 45-71. 


\section{ORÍGENES DEL DERECHO FUNDAMENTAL A LA BUENA ADMINISTRACIÓN PÚBLICA}

El origen formal del derecho fundamental a la buena Administración pública es normalmente asignado al derecho comunitario europeo. Sin embargo, antes de su reconocimiento en la Carta de Derechos Fundamentales de la Unión Europea en el año 2000, otras manifestaciones importantes de sus embriones pueden ser mencionadas.

Desde luego, la existencia de un deber de buena administración deriva de un principio jurídico homónimo, y por ello no es algo nuevo. Se trata de la imposición que desde hace mucho se reconoce como incidente sobre la actividad administrativa de los Estados permeados por una racionalidad republicana ${ }^{6}$. La Constitución italiana, desde 1947, establece en la parte inicial de su artículo 97 que "Los cargos públicos se organizarán según los preceptos de la ley, de tal modo que se garanticen su buen funcionamiento y la imparcialidad de la Administración" (bastardillas fuera del texto). Desde este dispositivo, los juristas de este país pasaron a deducir el "principio constitucional de buen funcionamiento de la Administración pública"7, al cual corresponde la obligación jurídica de desempeñar la función administrativa "de modo más congruente, más oportuno y más adecuado a los fines a ser alcanzados, gracias a la escogencia de los medios y de la ocasión para utilizarlos, concebidos como los más idóneos para los fines consagrados" ${ }^{\prime \prime}$. La buena administración, comprendida como un principio (norma que impone los parámetros de conducta a las instituciones públicas), era también invocada por la jurisprudencia de los tribunales europeos, como es el caso del entonces Tribunal de Justicia de las Comunidades Europeas ${ }^{9}$, que ya aplicaba dicho principio desde $1984^{[10]}$.

Sin embargo, la Carta de Derechos Fundamentales de la Unión Europea, aprobada en Niza en el año 2000, innovó al convertir el principio -hasta

6 La Constitución uruguaya de 1952 ya preveía en el segundo inciso del artículo 311 que la inobservancia de las reglas de buena administración consiste en fundamento para declarar la nulidad de los actos administrativos. Es dispositivo establecía que "Cuando la decisión declare la nulidad del acto en interés de la regla de derecho o de la buena administración, producirá efectos generales y absolutos". El significado jurídico de esta disposición constitucional es analizado por Aucusto Durán MARTíneZ, en "La buena administración", Estudios de Derecho Administrativo, n. ${ }^{\circ}$ 1, Montevideo: La Ley, 2010, pp. 173-194; y en Contencioso administrativo, Montevideo: Fundación de Cultura Universitaria, 2007, pp. 300 y ss.

7 ANTONIO ANDREANI, Il principio costituzionale di buon andamento della pubblica amministrazione, Padova: CEDAM, 1979.

8 Guido Falzone, Il dovere di buona amministrazione, Milan: Giuffrè, 1953, p. 64.

9 Con la entrada en vigor del Tratado de Lisboa, el 1. ${ }^{\circ}$ de diciembre de 2009, la Corte fue rebautizada como Tribunal de Justicia de la Unión Europea.

10 Referencias de las aplicaciones más significativas del principio de la buena administración por el Tribunal de Justicia se pueden encontrar en Luciano Parejo Alfonso et al., Manual de derecho administrativo comunitario, Madrid: CEURA, 2000, p. 85 . 
entonces tratado solamente bajo una perspectiva objetiva- en derecho bumano, otorgándole también una dimensión subjetiva susceptible de ser exigida ${ }^{11}$. Es en este punto donde los autores evidencian su capacidad modernizadora, identificándolo como el primer documento jurídico en alzar la buena administración al estatus de genuino derecho fundamental del ciudadano ${ }^{12}$. Cabe resaltar que el derecho en cuestión vino a abarcar otras facultades y garantías procesales que se diferencian del principio de la buena administración, y que ya habían ganado autonomía y sustancialidad propia ${ }^{13}$. Como se percibe, la formula utilizada no se limitó a reiterar la figura que hace tiempo ya era conocida, habiendo aportado una categoría con características peculiares y contornos a ser explorados.

La proclamación de la Carta fue fruto de la necesidad que se observó de acompañar, en el ámbito del derecho comunitario, la fuerte tendencia de los Estados-miembros de asegurar la tutela de los derechos del ser humano en sus constituciones internas y en tratados internacionales ${ }^{14}$. Esto porque el respeto a los derechos y las libertades fundamentales consiste en uno de los cimientos sobre el cual se apoya la entidad supranacional ${ }^{15}$. Prueba de esto es el artículo 7 del Tratado de la Unión Europea, según el cual la constatación de "una violación grave y persistente" de estos derechos autoriza al Consejo Europeo a deliberar para suspender "determinados derechos derivados de la aplicación de los tratados al Estado miembro de que se trate, incluidos los derechos de voto del representante del Gobierno de dicho Estado miembro en el Consejo".

La inserción del derecho a la buena administración en el aludido documento derivó básicamente de dos fenómenos. El primero fue de la actuación del Ombudsman europeo, al cual se le atribuyó, entre otras cosas, la tarea de conducir investigaciones sobre la mala administración de los órganos e institutos comunitarios, suministrando al Parlamento Europeo informes anuales y

11 Jesús Ángel Fuentetaja PAStor, "El derecho a la buena administración en la Carta de los derechos fundamentales de la Unión Europea", Revista de Derecho de la Unión Europea, n. ${ }^{\circ} 15$, Madrid: Colex, 2008, p. 137.

12 JACOB SöDERman, "El derecho fundamental a la buena administración", Gaceta Jurídica de la Unión Europea y de la Competencia, n. ${ }^{\circ}$ 214, Madrid: EINSA Multimedia, 2001, pp. 11; ANTONIO Fernández Tomás, La Carta de Derechos Fundamentales de la Unión Europea, Valencia: Tirant lo Blanch, 2001, p. 103.

13 Susana Galera Rodrigo, "El derecho a una buena administración", en Comentarios a la Constitución Europea, t. II, Los derechos y libertades, Valencia: Tirant lo Blanch, 2004, p. 1442.

14 El Tratado de Lisboa, firmado el 13 de diciembre de 2007, cuya vigencia inició en diciembre de 2009, incorporó por medio de su artículo 6, 1, la Carta de Derechos Fundamentales de Niza al conjunto normativo que rige la Unión Europea, confiriendo explícitamente el mismo valor jurídico de los tratados estructurantes del ente comunitario.

15 Álvaro RodríGuez Bereijo, "La Carta de los derechos fundamentales de la Unión Europea y la protección de los derechos humanos", en Unión Europea y derechos fundamentales en perspectiva constitucional, Madrid: Dykinson, 2004, p. 11 
recomendaciones al respecto ${ }^{16}$. Los informes de 1995 a 1999 fueron paulatinamente esculpiendo el concepto de mala administración que debía ser combatida ${ }^{17}$, sobre los cuales respondió el órgano parlamentario con resoluciones que terminaron recomendando la enunciación del derecho a la buena Administración pública, del cual debían ser titulares los ciudadanos comunitarios. El segundo factor de influencia fue la construcción jurisprudencial del Tribunal de Justicia de las Comunidades Europeas ${ }^{18}$, en cuyas decisiones se fueron reconociendo diversos derechos de los ciudadanos frente al propio ente supranacional y a las Administraciones públicas de los Estados-miembros ${ }^{19}$.

Esta actividad de la Corte, llamada a posicionarse sobre las contiendas relativas a los derechos que los ciudadanos de la Unión Europea tienen frente a la Administración pública (nacional y comunitaria), demostró que se hacía imperiosa una sistematización de los parámetros mínimos que deberían ser obligatoriamente obedecidos por las instituciones públicas de los paísesmiembros y del ente supraestatal. Es decir: se tornó imperativa la definición de un conjunto elemental de derechos fundamentales de observancia obligatoria, imprescindibles para la garantía de una Administración idónea. Fue con esta intención que en el año 2000 se recogió en el artículo 41 de la Carta de Niza el "derecho a una buena administración" en los siguientes términos:

16 Entre el $1 .{ }^{\circ}$ de septiembre de 1995 y el año 2000, el defensor del Pueblo europeo recibió más de 7000 reclamaciones, habiéndose incluido más de 1000 investigaciones sobre casos de mala administración. Las quejas trataban, entre otros temas, situaciones de morosidad administrativa, demora en efectuar pagos, falta de trasparencia, litigios sobre procedimientos de licitaciones y contratos, así como de selección del personal para los organismos comunitarios. JaCOB SÖDERMAN, óp. cit., p. 10.

17 Una de las modalidades de la mala administración -aunque no sea la única- es la corrupción. Sobre el tema, véase: Cristiana Fortini y Ariane Shermam, "Corrupção: causas, perspectivas e a discussão sobre o princípio do bis in idem", Revista de Investigações Constitucionais, vol. 5, n. ${ }^{\circ}$ 2, Curitiba: Capes, 2018, pp. 91-112; Luiz Alberto BlanChet y TÂmera PADOIN MARQues MARIN, "A corrupção como violação de direitos humanos e a necessária efetividade da Lei n. ${ }^{\circ}$ 12.846/13", $\mathrm{A}_{\&} \mathrm{C}$ - Revista de Direito Administrativo \& Constitucional, n. ${ }^{\circ} 71$, Belo Horizonte: Instituto de Direito Romeu Felipe Bacellar, 2018, pp. 267-294; Alfonso BUTELER, "Los sistemas para el control de la corrupción pública en el orden global", Revista de Direito Econômico e Socioambiental, vol. 8, n. ${ }^{\circ}$ 3, Curitiba: Pontificia Universidad Católica de Paraná, 2017, pp. 239-261; Andrés Fernando Ospina Garzón, "Instrumentos de la lucha contra la corrupción en Colombia: de la ultima ratio a la ausencia de razón", $A \& C$ - Revista de Direito Administrativo \& Constitucional, n. ${ }^{\circ}$ 63, Belo Horizonte: Instituto de Direito Romeu Felipe Bacellar, 2016, pp. 67-91.

18 Jaime RodríGuez-Arana MuÑoz, "El derecho fundamental al buen gobierno y a la buena administración de instituciones públicas", Revista de Estudios Locales (CUNAL), n. ${ }^{\circ}$ 100, Madrid: Thomson-Aranzadi, 2007, p. 44.

19 Un análisis detallado del papel del Ombudsman en la tutela de la buena administración y las diversas decisiones del Tribunal de Justicia de las Comunidades Europeas que constituyen precedentes a la enunciación del derecho ahora en discusión, es la realizada por VANICE Regina Lírio do VALLE, Direito fundamental à boa administração e governança, Belo Horizonte: Fórum, 2011, pp. 63-75. 
Artículo 41. Derecho a una buena administración

1. Toda persona tiene derecho a que las instituciones y órganos de la Unión traten sus asuntos imparcial y equitativamente y dentro de un plazo razonable.

2. Este derecho incluye en particular:

- el derecho de toda persona a ser oída antes de que se tome en contra suya una medida individual que le afecte desfavorablemente,

- el derecho de toda persona a acceder al expediente que le afecte, dentro del respeto de los intereses legítimos de la confidencialidad y del secreto profesional y comercial,

- la obligación que incumbe a la Administración de motivar sus decisiones.

3. Toda persona tiene derecho a la reparación por la Comunidad de los daños causados por sus instituciones o sus agentes en el ejercicio de sus funciones, de conformidad con los principios generales comunes a los derechos de los Estados miembros.

4. Toda persona podrá dirigirse a las instituciones de la Unión en una de las lenguas de los tratados y deberá recibir una contestación en esa misma lengua.

Como se deduce de la lectura del artículo, los derechos en él enumerados son conferidos a todas las personas que, por algún motivo, se relacionan con los órganos administrativos de la Unión Europea, de modo que su titularidad no se restringe a los portadores de la ciudadanía comunitaria ${ }^{20}$. Hay quienes sustentan, inclusive, que se trata del único derecho de la Carta cuyo ejercicio no figura condicionado por el requisito de nacionalidad o residencia en alguno de los Estados-miembros ${ }^{21}$.

\section{CONTENIDO JURÍDICO, POTENCIALIDADES \\ Y CONTRIBUCIONES DEL DERECHO A LA BUENA ADMINISTRACIÓN PÚBLICA PARA EL DERECHO ADMINISTRATIVO}

La primera cuestión que se encuentra después del análisis del dispositivo es saber si este derecho brinda alguna garantía jurídica innovadora, o sea, si agrega

20 Raffaele Bifulco, "Art. 41. Diritto ad una buona amministrazione", en L'Europa dei diritti: commento alla Carta dei dirittifondamentali dell'Unione Europea, Bologna: Società Editrice Il Mulino, 2001, p. 293.

21 Luis N. GonzÁLEz Alonso, "Artículo 41: Derecho a una buena administración", en Carta de los Derechos Fundamentales de la Unión Europea: comentario artículo por artículo, Bilbao: Fundación BBVA, 2008, p. 668. 
algún contenido de protección que no esté todavía asegurado por el sistema normativo de la Unión Europea. La respuesta aparentemente consensual en la doctrina es que los derechos contenidos en el artículo 41 de la Carta de Niza ya estaban en gran parte contemplados en el derecho comunitario y en la jurisprudencia comunitaria ${ }^{22}$. En ese contexto, el derecho a la buena Administración no inaugura nada inédito en materia de derechos en el suelo europeo, ya que la Carta se restringe a reunir sobre el mismo rótulo un abanico de derechos instrumentales o procedimentales ya consagrados en las decisiones de los tribunales europeos y, en algunos casos, por los propios tratados constitutivos de la Unión Europea ${ }^{23}$. Esta es una característica general del documento: aunque haya generado algunas novedades, aumentando y sistematizando los derechos de los ciudadanos europeos, la Carta de Niza consiste, en gran medida, en el resultado de la uniformización de diversos elementos que ya existían, siendo que muchos de ellos ya disfrutaban de vigencia jurídica incuestionable ${ }^{24}$.

El derecho fundamental a la buena Administración pública, en estos términos, se presenta como un derecho-sombrilla ${ }^{25}$, o un derecho-síntesis ${ }^{26}$, que alberga un haz de derechos fundamentales cuyo destinatario es el Estadoadministrador. En el caso europeo, conforme el modo como está estructurado el artículo 41, se determina un resumen de los derechos más relevantes que las personas tienen en sus relaciones con la Administración ${ }^{27}$, y por ello se dirige tanto a las instituciones y órganos que integran la Unión Europea, como a las Administraciones públicas nacionales cuando estén aplicando el derecho comunitario $^{28}$. Este nuevo derecho funciona como un epicentro aglutinador de las múltiples posiciones jurídicas de la ciudadanía, que encuentran en él una fuente normativo-axiológica común; así como el derecho a la tutela judicial efectiva, el cual reúne en su entorno los derechos de carácter procesal del ciudadano, direccionados al Estado-juez.

Por lo tanto, se cuida de un derecho-garantía, de índole instrumental ${ }^{29}$, dado que tiene por función propiciar la defensa de los derechos de carácter fundamental.

22 Beatriz Tomás MalléN, El derecho fundamental a una buena administración, Madrid: INAP, 2004 p. 45.

23 Jesús Ángel Fuentetaja Pastor, óp. cit., p. 144; Luis N. González Alonso, óp. cit., p. 665.

24 Lorenzo Martín-Retortillo Baquer, "Dos notas sobre la Carta", en La encrucijada constitucional de la Unión Europea, Madrid: Civitas, 2002, p. 184.

25 Utilizan esa expresión Luis N. GonZÁlez Alonso, óp. cit., p. 671, y Jesús ÁnGel FuenteTAjA PASTOR, óp. cit., p. 144.

26 JuAREZ FreITAS, Discricionariedade administrativa e o direito fundamental à boa administração pública, São Paulo: Malheiros, 2007, p. 15.

27 Jaime RodríGueZ-Arana MuÑoz, "El derecho fundamental al buen gobierno y a la buena administración de instituciones públicas", óp. cit., p. 45.

28 Para una apreciación detallada de los diversos órganos que figuran como sujetos pasivos del derecho fundamental a la buena administración pública, véase BeATRIZ TomÁs MalléN, óp. cit., pp. 51-57.

29 Vanice Regina Lírio do Valle, óp. cit., p. 81; Beatriz Tomás Mallén, óp. cit., p. 42. 
Esto porque al ser elevado a la categoría de derecho fundamental, se revela como una condición, un mecanismo para asegurar que otros derechos de igual naturaleza sean adecuadamente protegidos. La Carta de Niza, como se vio, realiza una expresa enumeración de diversos derechos, tales como la imparcialidad, la equidad y la razonable duración de los procesos administrativos, la motivación de las decisiones, la escucha previa frente a los actos que puedan afectar desfavorablemente la esfera jurídica del individuo, etc. No obstante, es importante resaltar que los derechos enunciados en el artículo 41 no son exhaustivos, sino meramente ejemplificativos ${ }^{30}$. Consiste en un conjunto mínimo de derechos que no excluye la vasta gama de otros derechos que el ciudadano titulariza frente a la Administración pública, muchos de los cuales ya eran antiguos y estaban protegidos por los tribunales comunitarios, aunque no existiera una enunciación normativa textual de su protección ${ }^{31}$.

Por ser un derecho de perfil abierto y contornos fluidos, carente de un contenido jurídico completamente autónomo, determinado y diferenciado (ya que su esencia es construida con otras posiciones iusfundamentales), no hay cómo negar el riesgo de que su proclamación pueda venir a transformarse en un "recurso meramente simbólico/retorico, que poco o nada añade al diseño constitucional" ${ }^{\prime 32}$. Esta ausencia de un objeto preciso llega a ser considerada, por algunos, como una limitación a la cualificación de la buena Administración pública como auténtico derecho fundamental, susceptible de reclamación ${ }^{33}$. Otros autores, diversamente, ven ese carácter vago no como un problema, sino como una ventaja, pues posee un carácter cambiante, evolutivo, que permite facilitar la conformación del concepto a los cambios que puedan ocurrir en el ámbito administrativo ${ }^{34}$.

¿Cuál sería, entonces, la finalidad de afirmar la buena Administración pública como derecho fundamental autónomo? En el contexto europeo, la formulación de este derecho tiene por objetivo resaltar la posición del ser humano y de sus derechos en su relación con los organismos comunitarios, produciendo un importante valor simbólico y político al subrayar el lugar que debe ser

30 Jesús Ángel Fuentetaja Pastor, óp. cit., p. 143; Luis N. González Alonso, óp. cit., pp. 666 y 671 .

31 Juan B. Lorenzo de Membiela trata de diecisiete derechos directamente relacionados con el derecho fundamental a la buena Administración pública que fueron reconocidos en diversas decisiones de los tribunales europeos, transcribiendo apartes de las sentencias ("La buena administración en la Administración general del Estado", Actualidad Administrativa, n. ${ }^{\circ}$ 4, Madrid: La Ley, 2007, pp. 407-414).

32 Vanice Regina Lírio do Valle, óp. cit., p. 23.

33 Javier García Roca, "Originario y derivado en el contenido de la Carta de los Derechos Fundamentales de la Unión Europea: los test de constitucionalidad y convencionalidad", Revista de Estudios Políticos, n. ${ }^{\circ} 119$, Madrid: Centro de Estudios Políticos y Constitucionales, 2003, p. 182.

34 Luis N. GonZález Alonso, óp. cit., p. 670. 
ocupado por la ciudadanía en el proceso de construcción europeo ${ }^{35}$. Así, uno de los objetivos de la inclusión de este derecho en la Carta de 2000 fue el de fortalecer la condición de ciudadano europeo frente a las instituciones públicas comunitarias y nacionales (cuando aplican el derecho comunitario), exigiendo para esto una reforma del modo de funcionamiento de la Administración pública. Además, dicho derecho ha logrado otorgar unidad a una multiplicidad de derechos acogidos de forma dispersa en los ordenamientos jurídicos de los Estados-miembros (en las constituciones o en las legislaciones nacionales) y en el ordenamiento comunitario (comprendiendo tanto las normas de los tratados que estructuran a la Unión Europea, como a los derechos suscritos por los propios órganos comunitarios, tales como el defensor del Pueblo y el Tribunal de Justicia de la Unión Europea) ${ }^{36}$. Por lo tanto, el propósito de su consignación en la Carta de Niza, en último análisis, consiste en organizar un conjunto básico de derechos instrumentales que sirvan de parámetro para el posterior control de la Administración europea ${ }^{37}$.

Es relevante anotar que la propia noción de "buena administración" puede dar lugar a cuestionamientos con relación a su significado. ¿Por qué el Poder Público tiene un deber de "buena" administración, y no de "optima" administración? Frente a varias opciones razonables e inseridas dentro de la actuación conferida al administrador por la norma jurídica, cel deber de "buena administración" no se cumpliría, aunque el agente escoja un medio idóneo, pero menos eficiente o eficaz? ¿No se estaría con eso admitiendo la posibilidad de escoger un mecanismo bueno en detrimento de uno óptimo para la consecución de la finalidad del acto? ¿No sería entonces más apropiada la imposición de un deber de eficiencia a la Administración pública, en el sentido de dirigir la actividad administrativa al alcance efectivo de la finalidad pública, disminuyendo de forma más sustancial la discrecionalidad del administrador? A no ser que se entienda lo "bueno" como si fuera "óptimo" (y parece ser esta la interpretación que está por detrás del concepto en estudio). Sin embargo, esta opción científica no deja de ser extraña, para no decir paradójica, pues lo bueno es apenas razonable, es decir, el mínimo satisfactorio frente a un objeto determinado. Pero además de esta cuestión semántica, parece ser exactamente otro el sentido que se busca imprimir al concepto de "buena Administración pública": un deber de administración optimizada de las instituciones públicas, que contiene no solo la idea de eficiencia, sino que también la ética, la transparencia, la imparcialidad y la equidad, entre muchas otras.

En esta línea, conviene subrayar que cuando se habla de "buena administración" no se está refiriendo a un juicio de valor, relacionado a la "bondad o 
maldad intrínseca de este o aquel modelo administrativo", pues el significado de la expresión habla sobre la adecuación del modo de administrar los fines que el ordenamiento jurídico destina al Estado ${ }^{38}$. Así, será buena la Administración pública $-\mathrm{y}$, por lo tanto, conforme al derecho fundamental aquí examinadoque obedezca plenamente, de forma óptima, a los principios y reglas que le son direccionados por el sistema constitucional (y comunitario, en el caso europeo).

Pero la gran potencialidad del derecho en discusión está, sin duda alguna, en el protagonismo que él otorga al ser humano en el palco del derecho público $^{39}$. Su virtud no reposa sobre la modesta lista hecha en el artículo 41 de la Carta de Niza, de algunos pocos derechos que el individuo posee frente a los entes públicos nacionales y comunitarios. El derecho a la buena Administración solo adquiere real importancia cuando supera la literalidad de su positivización y pasa a ser concebido como un norte para la actuación estatal y para la atribución de sentido al derecho administrativo y sus instituciones. En palabras de Jaime Rodríguez-Arana Muñoz, el "argumento medular" para la comprensión de este derecho consiste en la consideración central del ciudadano en las teorizaciones contemporáneas del derecho administrativo ${ }^{40}$.

Según el autor, hay un fundamento para declarar la buena administración como derecho fundamental. En él reside el hecho de que, en un escenario democrático, las instituciones públicas no son de propiedad de los políticos o de los altos funcionarios ${ }^{41}$, sino que son de los ciudadanos, "de las personas de carne y hueso que día a día, con su esfuerzo por encarnar los valores cívicos y las cualidades democráticas, dan buena cuenta del temple democrático en la cotidianeidad"42. Por este motivo, "si las instituciones públicas son de la soberanía popular, de donde proceden todos los poderes del Estado, es claro que han de estar ordenadas al servicio general, y objetivo, de las necesidades colectivas $^{\prime \prime 43}$. De esa premisa deviene, por consecuencia lógica, la preeminencia de reconocer un derecho a los individuos a que los intereses públicos sean

38 Vanice Regina Lírio do Valle, óp. cit., p. 24.

39 Carlos E. Delpiazzo, "Centralidad del administrado en el actual derecho administrativo: impactos del Estado constitucional de Derecho", Revista de Investigações Constitucionais, vol. 1, n. ${ }^{\circ}$ 3, Curitiba: Capes, 2014, pp. 7-32, Jaime Rodrícuez-Arana Muñoz, "Dimensiones del Estado social y derechos fundamentales sociales", Revista de Investigações Constitucionais, vol. 2, n. ${ }^{\circ}$ 2, Curitiba: Capes, 2015, pp. 31-62.

40 Jaime RodríGuez-Arana MuÑoz, "El derecho fundamental al buen gobierno y a la buena administración de instituciones públicas", óp. cit., p. 39.

41 En ese punto se manifiesta la conexión entre los principios democrático y republicano. Eneida Desiree Salgado, "Essay on the constitutional promises of democracy and republic", Revista de Investigações Constitucionais, vol. 4, n. ${ }^{\circ}$ 3, Curitiba: Capes, 2017, pp. 85-100.

42 Jaime Rodríguez-Arana MuÑoz, Direito fundamental à boa Administração Pública, Belo Horizonte: Fórum, 2012, p. 156.

43 JaIme RodríGuEZ-Arana MuÑoz, "Sobre el derecho fundamental a la buena administración y la posición jurídica del ciudadano", $A \& C$ - Revista de Direito Administrativo \& Constitucional, n. ${ }^{\circ} 47$, Belo Horizonte: Instituto de Direito Romeu Felipe Bacellar, 2012, p. 30. 
gestionados en consonancia con el libre desarrollo solidario de las personas. Por esta razón es que se trata de un derecho fundamental: "porque la persona en cuanto tal requiere que lo público, que el espacio de lo general, esté atendido de forma y manera que le permita realizarse, en su dimensión de libertad solidaria, como persona humana desde diferentes dimensiones" ${ }^{\prime \prime 4}$.

La principal contribución del derecho fundamental a la buena Administración pública está en reconectar la organización estatal con el ser humano, aproximándola del objetivo para el cual fue creada. Su afirmación demuestra la inadecuada forma de pensar el aparato administrativo de forma fetichiza$\mathrm{da}$, autorreferencial y autopoietica, dirigida exclusivamente a sus aspectos estructurales y organizacionales. Este nuevo derecho fundamental determina cómo el Poder Público debe funcionar en favor del ciudadano, destacando su carácter instrumental, en relación con la finalidad primordial de promoción del bienestar del pueblo ${ }^{45}$, a través de una actuación responsable, eficaz y direccionada a la consecución de los intereses de la colectividad estampados en el ordenamiento jurídico-constitucional. Con esto, el referido derecho impone que se vea la Administración pública desde la óptica de su función servicial, esto es, de servicio a la sociedad ${ }^{46}$. No como algo propio de una relación proveedor-cliente, sino, por el contrario, un servicio que invita al ciudadano a la participación social ${ }^{47}$. Como bien afirma Rodríguez-Arana Muñoz, el individuo deja de ser "un sujeto inerte, inerme e indefenso frente a un poder que intenta controlarlo, que le prescribía lo que era bueno o malo para él, al que estaba sometido", para convertirse en "un sujeto activo, protagonista, persona en su más cabal expresión, y, por ello, aspira a tener una participación destacada en la configuración de los intereses generales" ${ }^{\prime \prime 8}$. En última instancia: deja de ser administrado y pasa a ser, verdaderamente, ciudadano.

44 Jaime Rodríguez-Arana MuÑoz, "El derecho fundamental a la buena administración en la Constitución española y en la Unión Europea", A\&C - Revista de Direito Administrativo \& Constitucional, n. ${ }^{\circ}$ 40, Belo Horizonte: Instituto de Direito Romeu Felipe Bacellar, 2010, p. 135 .

45 Emerson Gabardo, "O princípio da supremacia do interesse público sobre o interesse privado como fundamento do Direito Administrativo Social", Revista de Investigações Constitucionais, vol. 4, n. ${ }^{\circ}$ 2, Curitiba: Capes, 2017, pp. 95-130.

46 Augusto Durán Martínez, "Estado constitucional de derecho y servicios públicos", $A \& C$ - Revista de Direito Administrativo \& Constitucional, n. ${ }^{\circ}$ 60, Belo Horizonte: Instituto de Direito Romeu Felipe Bacellar, 2015, pp. 39-62.

47 Jaime Rodríguez-Arana Muñoz, "La participación en el Estado social y democrático de Derecho", A\&C - Revista de Direito Administrativo \& Constitucional, n. ${ }^{\circ} 48$, Belo Horizonte: Instituto de Direito Romeu Felipe Bacellar, 2012, p. 16; Silvia Carmona Garias, "Nuevas tendencias en la participación ciudadana en España: ¿socializando la gestión pública o socializando la responsabilidad política?", A\&C - Revista de Direito Administrativo \& Constitucional, n. ${ }^{\circ} 66$, Belo Horizonte: Instituto de Direito Romeu Felipe Bacellar, 2016, pp. 29-60.

48 Jaime Rodríguez-Arana MuÑoz, "Sobre el derecho fundamental a la buena administración y la posición jurídica del ciudadano", óp. cit., p. 30 
Esta forma de pensar la máquina estatal proyecta luces sobre el modo de mirar todo el derecho administrativo y sus categorías elementales. Ella implica el abandono del estudio de esta rama jurídica centrada excesiva y únicamente en la perspectiva de la organización de la Administración pública, analizada en su estructura sobre diferentes ángulos en abordajes cerrados, desvinculados de su dimensión social y despreocupados con su verdadera razón de ser: la atención a las necesidades de la ciudadanía ${ }^{49}$. El viraje en la comprensión de esta rama jurídica, que se pretende llevar a cabo mediante la consagración de un derecho fundamental a la buena Administración, se manifiesta en el reposicionamiento de las prerrogativas y privilegios especiales tradicionalmente conferidos al Estado, relativos a los poderes de imponer unilateralmente conductas a los particulares en el ámbito de los actos, contratos y procedimientos administrativos ${ }^{50}$. Se opera una reinterpretación de las potestades públicas a partir de los cimientos erigidos por el ropaje constitucional del Estado social y democrático de derecho, en pro de la dignidad de la persona humana y de los derechos fundamentales ${ }^{51}$.

\section{EL DERECHO FUNDAMENTAL A LA BUENA ADMINISTRACIÓN PÚBLICA EN EL DERECHO BRASILERO}

Es con base en esta lógica que el derecho a la buena Administración pública es introducido en el contexto del derecho público brasilero, ganando la aceptación de la doctrina ${ }^{52}$ y de la jurisprudencia ${ }^{53}$ nacional. Su puerta de entrada

Jaime RodríGuez-Arana MuÑoz, "El derecho fundamental a la buena administración en la Constitución española y en la Unión Europea", óp. cit., p. 121

50 Sobre esas transformaciones del derecho administrativo en el siglo XXI, véase: EuRICO Bitencourt Neto, "Transformações do Estado e a Administração Pública no século XXI", Revista de Investigações Constitucionais, vol. 4, n. ${ }^{\circ}$ 1, Curitiba: Capes, pp. 207-225; José ManueL Sérvulo Correia, "Os grandes traços do direito administrativo no século XXI", A\&C - Revista de Direito Administrativo \& Constitucional, n. ${ }^{\circ}$ 63, Belo Horizonte: Instituto de Direito Romeu Felipe Bacellar, 2016.

51 Juan Gustavo Corvalán, "Transformações do 'regime de Direito Administrativo': a propósito do regime exorbitante e das prerrogativas da Administração Pública", $A \& C$ - Revista de Direito Administrativo \& Constitucional, n. ${ }^{\circ}$ 51, Belo Horizonte: Instituto de Direito Romeu Felipe Bacellar, 2013, pp. 66 y 68; Jaime Rodrícuez-Arana MuÑoz, "El derecho administrativo ante la crisis (El derecho administrativo social)", $A \& C$ - Revista de Direito Administrativo \& Constitucional, n. ${ }^{\circ}$ 60, Belo Horizonte: Instituto de Direito Romeu Felipe Bacellar, 2015.

52 Además de las obras citadas en las próximas notas, reconocen el derecho a la buena administración, entre otros: Celso Antônio BandeIRA De Mello, Curso de Direito Administrativo, 30. ${ }^{a}$ ed., São Paulo: Malheiros, 2013, p. 126; Ingo WolfGang Sarlet, A eficácia dos direitos fundamentais: uma teoria geral dos direitos fundamentais na perspectiva constitucional, 10. ${ }^{a}$ ed., Porto Alegre: Livraria do Advogado, 2010, p. 90; Julio CeSAR FINGER, "O direito fundamental à boa administração e o princípio da publicidade administrativa" Interesse Público, n. ${ }^{\circ} 58$, Belo Horizonte: Instituto Brasileiro de Altos Estudos de Direito Público, 2009, pp. 133-143; Gustavo Henrique Justino de Oliveira y Julieta Mendes Lopes VareschinI, "Administração 
fue la monografía publicada por Juarez Freitas en 2007, en la cual sustentó el autor que "el derecho fundamental a la buena administración pública [...] es norma implícita de directa e inmediata eficacia en nuestro sistema constitucional ${ }^{\prime \prime 54}$. Posteriormente, su desarrollo en territorio brasilero fue impulsado por la contribución de la obra de Vanice Lírio do Valle sobre el tema ${ }^{55}$. La inexistencia de una previsión constitucional específica que determine el derecho a la buena Administración pública de forma expresa no impide su reconocimiento como pretensión jurídica dotada de carácter de derecho fundamental, dada la naturaleza abierta del catálogo de derechos fundamentales en la Constitución brasilera, conforme lo determina el artículo $5, \S 2{ }^{\circ[56]}$. Este derecho deriva de los principios fundamentales del título I de la Constitución, tales como la ciudadanía y la dignidad de la persona humana ${ }^{57}$ (artículo 1, II y III), y de los objetivos de construcción de una sociedad libre, justa y solidaria y de promoción del bien de todos (artículo 3, II y IV), además de relacionarse íntimamente con los principios regentes de la Administración

pública brasileira e os 20 anos da Constituição de 1988: momento de predomínio das sujeições constitucionais em face do direito fundamental à boa administração pública", Fórum Administrativo, n. ${ }^{\circ}$ 95, Belo Horizonte: ed. Fórum, 2009, pp. 23-34, Luís ManueL FOnSECA PIRES, "Responsabilidade civil do Estado por insuficiência da segurança pública", en Responsabilidade civil do Estado: desafios contemporâneos, São Paulo: Quartier Latin, 2010 pp. 717-738; Rafael Veras de Freitas, "O dever de planejamento como corolário ao direito fundamental à boa Administração Pública", en Direito Administrativo: estudos em bomenagem a Francisco Mauro Dias, Rio de Janeiro: Lumen Juris, 2009, Felipe Esteves Grando, "O direito fundamental à boa administração pública e seu diálogo com o Direito Tributário", Interesse Público, n. ${ }^{\circ}$ 59, Belo Horizonte: Instituto Brasileiro de Altos Estudos de Direito Público, 2010, pp. 215-225.

53 Apenas para citar algunas decisiones que hacen expresa alusión al derecho fundamental a la buena Administración pública, a título de ejemplo están las siguientes sentencias: BrASIL, Tribunal Regional Federal da 4. ${ }^{a}$ Região, Apelação e Reexame Necessário n. ${ }^{\circ} 5025299$ 96.2011.404.7100. Sexta Turma. Relator p/ Acórdão Celso Kipper. D.E. 16.09.2013, BrasiL, Tribunal Regional Federal da 4. ${ }^{a}$ Região, Agravo de Instrumento n. ${ }^{\circ} 5017280$ 90.2013.404.0000, Terceira Turma, Relator Nicolau Konkel Júnior. D.E. 05.08.2013; BRASIL, Tribunal Regional Federal da 4. ${ }^{a}$ Região. Apelação Cível n. ${ }^{\circ}$ 5013872-90.2011.404.7201, Terceira Turma, Relatora Maria Lúcia Luz Leiria. D.E. 25.11.2012; BRASIL, Tribunal Regional Federal da 4. ${ }^{a}$ Região, Apelação Cível n. ${ }^{\circ}$ 5039808-95.2012.404.7100, Terceira Turma, Relator Carlos Eduardo Thompson Flores Lenz. D.E. 14.06.2013.

54 JuAREZ FreITAS, Discricionariedade administrativa e o direito fundamental à boa administração pública, óp. cit., p. 7.

55 Vanice Regina Lírio do Valle, Direito fundamental à boa administração e governança, óp. cit., 2011.

56 Constitución de la República Federativa del Brasil (1988) "Art. 5. ${ }^{\circ}[\ldots]$ §2. ${ }^{\circ}$ Los derechos y garantías expresos en esta Constitución no excluyen otros derivados del régimen de los principios por ella adoptados, o de los tratados internacionales en que la República Federativa del Brasil sea parte".

57 Orides Mezzaroba y Vladmir Oliveira da Silveira, "The principle of the dignity of human person: A reading of the effectiveness of citizenship and human rights through the challenges put forward by globalization", Revista de Investigações Constitucionais, vol. 5, n. ${ }^{\circ} 1$, Curitiba: Capes, 2018, pp. 273-293. 
pública, expuestos en el artículo 37 (legalidad, impersonalidad, publicidad, moralidad y eficiencia).

Es evidente que, con respecto a su composición jurídica, el derecho a la buena Administración en el sistema normativo brasilero gana delineamientos propios, siendo inadecuada cualquier tentativa de asociarlo o fundamentarlo conforme la redacción del artículo 41 de la Carta de Derechos Fundamentales de la Unión Europea, con el objetivo de restringir a ella su significado. La lectura del citado dispositivo llevaría, de inmediato, a la inferencia de que él no dirige absolutamente ninguna novedad para el derecho administrativo patrio ${ }^{58}$. Un breve análisis puede dejar entrever, con seguridad, que limitarse a los enunciados establecidos en el artículo 41 del documento europeo no aumenta en nada el patrimonio jurídico del ciudadano brasilero ${ }^{59}$. Es cierto que, por tratarse de una declaración de derechos internacionales, que incluye varios países, la Carta de Niza debió limitarse a un núcleo reducido de derechos para lograr la aceptación del mayor número posible de Estados-miembros. No obstante, si se comparan los derechos que la Constitución brasilera de 1988 estableció a la Administración pública con los derechos fijados en el artículo 41 de la Carta Europea, no hay dudas de que el documento jurídico brasilero va más allá en términos de fijar parámetros y deberes de actuación administrativa y de

58 A esta misma conclusión llega Glaciela Ruocco al comparar el contenido descrito en el artículo 41 de la Carta de Niza con el ordenamiento jurídico uruguayo, señalando enseguida que en virtud de la creación del derecho fundamental a la buena Administración pública reside, por otro lado, en "resumir en esta expresión la formulación de la nueva forma de concebir la relación de la Administración con los ciudadanos y de construir esta relación como un derecho de estos". Graciela Ruocco, "La 'buena administración' y el 'interés general'", $A_{\&} C$ - Revista de Direito Administrativo \& Constitucional, n. ${ }^{\circ} 49$, Belo Horizonte: Instituto de Direito Romeu Felipe Bacellar, 2012, p. 35.

59 El deber de trato imparcial, equitativo y en plazo razonable del artículo 41.1 ya se encuentra previsto en el artículo 37 de la Constitución brasilera (principio de impersonalidad) y en el artículo 5, LXXVIII (derecho fundamental a la razonable duración del proceso administrativo). Sobre las previsiones del artículo 41.2: a) el derecho a ser escuchado antes de ser afectado por una medida administrativa desfavorable se encuentra en el artículo 5, LIV (debido proceso legal) y LV (contradicción y amplia defensa) de la Constitución brasilera ; b) el derecho a tener acceso a los procesos de su interés particular es garantizado por el artículo 5, XXXIII (acceso a la información) de la Constitución brasilera, c) la obligación de motivación de las decisiones deriva del artículo 37 de la Constitución brasilera (principio de publicidad) y del artículo 50 de la Ley n. ${ }^{\circ} 9784 / 99$, que la prevé expresamente. El derecho a la reparación de daños es asegurado por el artículo $37, \S 6 .^{\circ}$ (responsabilidad civil del Estado) de la Constitución brasilera. Finalmente, el derecho del artículo 41.4, de dirigirse a la Administración en cualquiera de las lenguas oficiales de los tratados y recibir respuesta en el mismo idioma, no se aplica al caso brasilero, pues la lengua oficial es el portugués (artículo 13 de la Constitución brasilera). 
determinar garantías al ciudadano para asegurar su observancia por parte del aparato estatal ${ }^{60}$.

En este punto, desarrollando una síntesis de derechos que la persona ostenta en sus relaciones con la Administración pública, Juarez Freitas realiza una fusión entre los más importantes principios constitucionales que inciden sobre la función administrativa para forjar su definición, de ropaje brasilero, del derecho fundamental en referencia. El autor conceptúa la buena administración como un derecho a la "administración pública eficiente y eficaz, proporcional cumplidora de sus deberes, con transparencia, motivación, imparcialidad y respeto a la moralidad, a la participación social y a la plena responsabilidad por sus conductas omisivas y comisivas", al cual corresponde "el deber de la Administración pública de observar, en las relaciones administrativas, la coherencia de la totalidad de los principios constitucionales que la rigen" ${ }^{\prime \prime}$. Sin pretensión de exhaustividad, Freitas extrae de ese derecho, a título de ejemplo, los siguientes contenidos: a) derecho a una administración transparente, respetuosa del principio de publicidad; b) derecho al contradictorio, a la amplia defensa y al debido proceso (con duración razonable) ${ }_{i}$ c) derecho a la motivación y a las decisiones proporcionales; d) derecho a una administración imparcial, e) derecho a una administración proba y ética f) derecho a la legalidad temperada, que presupone el respeto a la ley sin una aplicación ciega de las reglas jurídicas; g) derecho a la participación social, h) derecho a una administración eficiente y eficaz; e i) derecho a la reparación de los daños causados por la Administración ${ }^{62}$.

Es posible observar que gran parte de estos derechos ya tienen asiento constitucional explícito. De esta constatación pueden surgir -ahora en el contexto brasilero- dudas sobre si el derecho a la buena Administración pública es o no un derecho fundamental, así como su existencia, como derecho dotado de contenido propio. Si solo es un conjunto de derechos fundamentales específicos y autónomos que se dirigen a la Administración pública, ¿cuál sería su relevancia jurídica? ¿En qué se distingue de los demás derechos? ¿Por qué, al final, tiene sentido defender su vigencia en el derecho brasilero? ¿Su función no sería meramente retórica? Tales indagaciones, a simple vista, pueden conducir a la conclusión de que el derecho en discusión no ostenta suficiente importancia para alcanzar la condición de verdadero derecho fundamental. Pero esta respuesta no parece ser la más acertada. La justificación para el reconocimiento

60 En esta línea, INGo WolfGang SARLET, A Administração Pública e os direitos fundamentais. Classe impartida em la Escola da Magistratura do Tribunal Regional Federal da 4. ${ }^{a}$ Região (transcripción), p. 2. Disponible en línea: http://www2.trf4.jus.br/trf4/upload/arquivos/ emagis_atividades/ingowolfgangsarlet.pdf [consultado el 5 de agosto de 2018].

61 JuAREZ FreITAS, Discricionariedade administrativa e o direito fundamental à boa administração pública, óp. cit., p. 20.

62 Ibíd., pp. 20-21. 
al derecho a la buena Administración pública en el contexto constitucional brasilero se encuentra en por lo menos tres factores.

El primero de ellos, de naturaleza simbólica, ya fue explicado antes. Este derecho altera el foco del análisis jurídico-político de la relación entre el ciudadano y la Administración, desplazando la atención de la Administración para el ciudadano y, con esto, enfatizando el carácter servicial del Poder Público para con la persona humana. El objetivo del derecho administrativo deja de ser simplemente la disciplina jurídica que trata sobre la estructura y el funcionamiento de la Administración pública, para pasar a estudiar la forma de regular el aparato administrativo con la intención de garantizar la realización plena y eficaz de los derechos fundamentales y del interés general, en donde el titular principal es la colectividad. Esto produce impactos significativos en la interpretación de diversas figuras de esta rama del derecho. Es lo que se observa en la obra de Juarez Freitas, cuando propone la relectura de institutos como el control judicial de los actos administrativos, la responsabilidad del Estado, la autorización del servicio público, la convalidación del acto administrativo, el poder de policía administrativa y las carreras de Estado. Todas estas instituciones pasan ahora a ser vistas esencialmente desde la perspectiva del ser humano, y no más sobre la perspectiva exclusiva de los poderes y las potestades de la Administración ${ }^{63}$.

El segundo motivo que demuestra la relevancia de la identificación del derecho a la buena Administración pública es de naturaleza jurídica, y reside en el hecho de que de él pueden ser deducidas pretensiones iusfundamentales que no se encuentran explícitamente enunciadas en el texto de la Constitución. Una vez consideradas como desarrollos de este derecho más amplio y revestido de estatus de derecho fundamental, es posible elevar tales posiciones jurídicas al nivel constitucional, extendiendo a ellas el régimen iusfundamental. Para citar apenas un ejemplo, es este el caso del derecho a la protección de la confianza legitima y de la buena fe, que actualmente encuentra amplia aceptación doctrinal en Brasi $^{64}$ y en otros países ${ }^{65}$, como barrera a la prerrogativa de la Administración

63

64 Almiro do Couto Silva, "O princípio da segurança jurídica (proteção à confiança) no direito público brasileiro e o direito da administração pública de anular seus próprios atos administrativos: o prazo decadencial do art. 54 da lei do processo administrativo da União (Lei n. ${ }^{\circ}$ 9784/99)", Revista Brasileira de Direito Público, n. ${ }^{\circ}$ 6, Belo Horizonte: Forum, 2004; Celso Antônio Bandeira de Mello, "A estabilidade dos atos administrativos e a segurança jurídica, boa-fé e confiança legítima ante atos estatais", Grandes Temas de Direito Administrativo, São Paulo: Malheiros, 2009, pp. 168-180; Maria Sylvia Zanella di Pietro, "Os princípios da proteção à confiança, da segurança jurídica e da boa-fé na anulação do ato administrativo", en Direito Público Atual: Estudos em homenagem ao Professor Nelson Figueiredo, Belo Horizonte: Fórum, 2008, pp. 295-316; RAFAel MAFFINI, Princípio da proteção substancial da confiança no Direito Administrativo brasileiro, Porto Alegre: Verbo Jurídico, 2006; RAfael VaLim, O princípio da segurança jurídica no Direito Administrativo brasileiro, São Paulo: Malheiros, 2010, 
de anular actos viciados de los cuales surten efectos favorables a los destina$\operatorname{tarios}^{66}$. Dicho derecho no está formalmente enunciado en la Constitución de 1988, pero se debe presumir que es un genuino derecho fundamental, dada su similitud con los derechos establecidos en el título II ("De los derechos y las garantías fundamentales") y su derivación directa del régimen democrático adoptado por la Ley Fundamental. Admitir la existencia de un derecho fundamental a la buena Administración pública, con base en el argumento que de él procede el derecho a la protección de la confianza legítima y de la buena fe del individuo, implica aceptar su inclusión en el conjunto de derechos materialmente fundamentales. Además, esta correlación entre los mencionados derechos y el derecho a la buena Administración ya fue realizada por el Tribunal Superior de Justicia como mecanismo para salvaguardar la seguridad jurídica del ciudadano ${ }^{67}$.

pp. 111-130; Fernando Dias Menezes de Almeida, "Princípios da Administração Pública e segurança jurídica", en Tratado sobre o princípio da segurança jurídica no Direito Administrativo, Belo Horizonte: Fórum, 2013, pp. 47-63.

65 Jaime Rodríguez-Arana Muñoz, "Los principios de seguridad jurídica, buena fe y confianza legítima", en Tratado sobre o princípio da segurança jurídica no Direito Administrativo, Belo Horizonte: Fórum, 2013, pp. 131-148; Jesús GONZÁLEZ PÉREZ, El principio general de la buena fe en el derecho administrativo, 5. ${ }^{\text {a }}$ ed., Madrid: Civitas - Thomson Reuters, 2009; FedERICO A. Castillo Blanco, La protección de confianza en el derecho administrativo, Madrid: Marcial Pons, 1998; SOREn J. SCHOnBerG, Legitimate expectations in administrative law, Oxford: Oxford, 2000; Sylvia Calmes, Du principe de protection de la confiance légitime en droits allemand, communautaire et français, Paris: Dalloz, 2001; Javier García LuENGO, El principio de protección de la confianza en el derecho administrativo, Madrid: Civitas, 2002; Pedro Coviello, La protección de la confianza del administrado: Derecho argentino y derecho comparado, Buenos Aires: Abeledo-Perrot, 2004.

Weida Zancaner, Da Convalidação e da Invalidação dos Atos Administrativos, 3. a ed., São Paulo: Malheiros, 2008; Romeu Felipe BaCellar Filho, "A estabilidade do ato administrativo criador de direitos à luz dos princípios da moralidade, da segurança jurídica e da boa-fé", $A \& C$ - Revista de Direito Administrativo \& Constitucional, n. ${ }^{\circ}$ 40, Belo Horizonte: Instituto de Direito Romeu Felipe Bacellar, 2010, pp. 291-313; ANA ClÁUdiA FinGER, "O princípio da boa-fé e a supremacia do interesse público - Fundamentos da estabilidade do ato administrativo", en Direito Administrativo e Interesse Público: Estudos em bomenagem ao Professor Celso Antônio Bandeira de Mello, Belo Horizonte: Fórum, 2010, pp. 307-346, Rocério Gesta Leal, "A estabilidade do ato administrativo criador de direitos: reflexões para o Brasil", en El acto administrativo como fuente del derecho administrativo en Iberoamérica, Panamá: Congrex, 2009, pp. 119-135.

67 Es interesante observar aparte de la Sentencia: "ADMINISTRATIVO - AUSENCIA DE VIOLACIÓN DEL ART. 535 DEL CPC - TERCER ADQUIRIENTE DE AUTOMÓVIL - CERTIFICADO DE REGISTRO DE VEHÍCULO EMITIDO SIN ANOTACIÓN DE NINGÚN GRAVAMEN - ULTERIOR IMPORTACIÓN DE RESTRICCIONES PRETÉRITAS - VIOLACIÓN DE LA BUENA FE Y DEL PRINCIPIO DE LA CONFIANZA. 1. El recurrente adquirió un automóvil, sobre el cual no existía ningún gravamen registrado en el órgano de transito ni en la emisión del Certificado de Registro y Licencia del Vehículo también no constaba ninguna observación. Posteriormente cuando la autarquía pasó a integrar el Sistema Nacional de Gravamen, la importación determinó restricciones pretéritas. 2. La situación descrita transgrede el principio según el cual se debe proteger a los terceros de buena fe. Agrede también la confianza que debe existir entre los administrados y el Poder Público, en último análisis, viola el derecho fundamental a la buena administración pública" (cursiva nuestra). BRASIL, Superior Tribunal 
El tercer elemento, también de carácter jurídico, que testifica la virtud de afirmar la autonomía de un derecho a la buena Administración pública es la posibilidad de permitir hacer exigible -sea por el ciudadano, o por grupos determinados o indeterminables- el cumplimiento de los principios constitucionales que rigen la función administrativa. Por ejemplo: la atención a los principios determinados en el artículo 37 de la Constitución, como legalidad, publicidad, impersonalidad, moralidad y eficiencia (apenas para citar algunos de los que se encuentran expresos en el enunciado normativo), deja de ser concebido solamente como un deber objetivo a ser perseguido por los agentes públicos. Pasa a ser visto, ahora, como un derecho fundamental de los ciudadanos, con asiento constitucional, que no depende de concretización legal o reglamentos sobre su contenido específico para autorizar su invocación, y se podrá presentar como una pretensión jurídica de titularidad individual o transindividual. En el primer caso, se puede citar la situación de un servidor que es sancionado en un procedimiento disciplinario, conducido por una comisión formada por miembros personalmente interesados en el resultado negativo del juicio, violándose el derecho a la Administración impersonal. Esto, independientemente de la existencia o no, en la esfera de la federación en cuestión, de una ley de procedimiento administrativo (estatal, municipal, etc.) que fije las hipótesis de impedimento. El derecho a la imparcialidad en el procedimiento deviene directamente del artículo 37 de la Constitución. Por otro lado, el derecho a la buena Administración podrá también revelarse como una posición jurídica de titularidad transindividual, tal como en las situaciones de gestión deshonesta y fraudulenta del patrimonio público, ofensiva al derecho a una Administración proba y ética.

El objetivo específico de este derecho en cada Estado podrá ser identificado más fácilmente a partir de la apreciación en concreto de su respectivo orden jurídico constitucional y legal. Sin embargo, existen autores que buscan trazar un panorama de diversos derechos del ciudadano en sus relaciones con las instituciones públicas, cuya tutela se juzga recomendable para que se garantice plenamente el derecho fundamental a la buena Administración. Son pretensiones jurídico-subjetivas que, en principio, aunque no sean previstas textualmente, pueden ser extraídas implícitamente de este derecho fundamental, desde que no se muestren incompatibles con el sistema normativo en el cual el individuo está inserido. Se trata de una forma de inspirar a los países que acogen el principio de Estado democrático de derecho, sugiriéndoles la inclusión de una serie de derechos y garantías en sus ordenamientos jurídicos.

El mayor ejemplo de esta iniciativa es la Carta Iberoamericana de Derechos y Deberes del Ciudadano en relación con la Administración pública, aprobada 
el 10 de octubre de 2013 por el Centro Latinoamericano de Administración para el Desarrollo (CLAD), cuya redacción fue confiada por el Consejo Directivo de la entidad al profesor Jaime Rodríguez-Arana Muñoz ${ }^{68}$. De acuerdo con su capítulo primero, ítem 1, la Carta anuncia tener como finalidad "el reconocimiento del derecho fundamental de la persona a la buena Administración pública y de sus derechos y deberes componentes", posibilitando que los ciudadanos iberoamericanos puedan "asumir una mayor conciencia de su posición central en el sistema administrativo y, de esta forma, poder exigir de las autoridades, funcionarios, agentes, servidores y demás personas al servicio de la Administración pública, actuaciones caracterizadas siempre por el servicio objetivo al interés general y consecuente promoción de la dignidad humana"69. La Declaración otorga una explicación sobre el significado de este derecho, estableciendo en el numeral 25 del capítulo tercero que: "Los ciudadanos son titulares del derecho fundamental a la buena Administración pública, que consiste en que los asuntos de naturaleza pública sean tratados con equidad, justicia, objetividad, imparcialidad, siendo resueltos en plazo razonable al servicio de la dignidad humana". El mismo dispositivo establece que su contenido, en concreto, "se compone, entre otros, de los derechos señalados en los artículos siguientes, que se podrán ejercer de acuerdo con lo previsto por la legislación de cada país". El documento logró detallar la composición jurídica de este derecho general en los numerales subsecuentes del mismo capítulo.

En obra monográfica sobre el tema, anterior a la elaboración de la declaración, Rodríguez-Arana Muñoz-redactor del proyecto-ya arrojaba veinticuatro principios jurídicos que reputaba como centrales del derecho fundamental a la buena Administración pública, cuya obediencia sería necesaria para que este último se considerara respetado ${ }^{70}$. Identificaba, además, treinta y un derechos

68 La Administración al Día, El catedrático Rodríguez-Arana redactará la Carta de Derechos Ciudadanos de Iberoamérica, óp. cit.

69 Centro Latinoamericano de Administración para el Desarrollo, Carta Iberoamericana de los Derechos y Deberes del Ciudadano en Relación con la Administración Pública. Caracas, 2013. Disponible en línea: http://www.clad.org/documentos/declaraciones/Carta\%20 Iberoamericana \%20de\%20los\%20deberes\%20y\%20derechos\%20-\%20documento\%20 aprobado.pdf/view [consultado el 5 de agosto de 2018].

70 El autor alude a los siguientes principios, explicando enseguida el contenido de cada uno de ellos: a) principio de juridicidad ${ }_{i}$ b) principio de servicio objetivo a los ciudadanos; c) principio promocional ${ }_{i}$ d) principio de racionalidad ${ }_{i}$ e) principio de igualdad de trato f) principio de eficacia $;$ g) principio de publicidad de las normas, de los procedimientos y del entero quehacer administrativo en el marco del respeto del derecho a la intimidad y de las reservas que por razones acreditadas de confidencialidad o interés general sea pertinente en cada caso, en los procedimientos para el dictado de actos administrativos $;$ h) principio de seguridad jurídica, de previsibilidad y certeza normativa $a_{i}$ i) principio de pro-

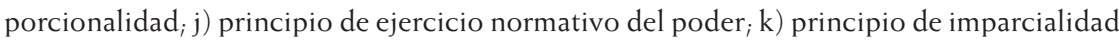
e independencia ${ }_{i}$ ) principio de relevancia ${ }_{i} \mathrm{~m}$ ) principio de coherencia ${ }_{i} \mathrm{n}$ ) principio de buena $\mathrm{fe}_{;} \tilde{\mathrm{n}}$ ) principio de confianza legítima $;$ o) principio de asesoramiento ${ }_{i}$ p) principio 
específicos que provienen de este derecho-síntesis, sin perjuicio de otros, demostrando con esto la amplitud de la protección por él conferida al ciudadano en su trato con los poderes públicos ${ }^{71}$. La mayoría de los principios y derechos derivados del derecho fundamental a la buena Administración pública

de responsabilidad $;$ q) principio de facilitación ${ }_{i}$ r) principio de celeridad; s) principio de transparencia y acceso a la información de interés general ${ }_{i}$ t) principio de protección de la intimidad $\mathrm{u}_{i}$ ) principio de ética ${ }_{i}$ ) principio de debido proceso $_{i}$ y w) principio de cooperación. Jaime RodríGuez-Arana MuÑoz, Direito fundamental à boa Administração Pública, óp. cit., pp. 169-172.

71 "El derecho general fundamental de los ciudadanos a una buena Administración pública finalmente, se puede concretar, entre otros, en los siguientes derechos subjetivos de orden administrativo: 1) derecho a la motivación de las actuaciones administrativas; 2 2) derecho a la tutela administrativa efectiva $; 3$ ) derecho a una resolución administrativa en plazo razonable $_{;} 4$ ) derecho a una resolución justa de las actuaciones administrativas; 5 ) derecho a presentar por escrito o de palabra peticiones de acuerdo con lo que se establezca en las normas, en los registros físicos o informáticos; 6) derecho a respuesta oportuna y eficaz de las autoridades administrativas; 7 ) derecho a no presentar documentos que ya obren en poder de la Administración pública $;$ ) derecho a ser oído siempre antes de que se adopten medidas que les puedan afectar desfavorablemente $\left.{ }_{i} 9\right)$ derecho de participación en las actuaciones administrativas en que tengan interés, especialmente a través de audiencias y de informaciones públicas; 10 ) derecho a una indemnización justa en los casos de lesiones de bienes o derechos como consecuencia del funcionamiento de los servicios de responsabilidad pública, 11 ) derecho a servicios públicos y de interés de general de calidad, 12) derecho a elegir los servicios de interés general de su preferencia $\left.{ }_{i} 13\right)$ derecho a opinar sobre el funcionamiento de los servicios de responsabilidad administrativa $\left.{ }_{i} 14\right)$ derecho a conocer las obligaciones y compromisos de los servicios de responsabilidad administrativa 15) derecho a formular alegaciones en cualquier momento del procedimiento adminis trativo; 16) derecho a presentar quejas, reclamaciones y recursos ante la Administración, 17) derecho a interponer recursos ante la autoridad judicial sin necesidad de agotar la vía administrativa previa, de acuerdo con lo establecido en las leyes; 18 ) derecho a conocer las evaluaciones de los entes públicos y a proponer medidas para su mejora permanente; 19) derecho de acceso a los expedientes administrativos que les afecten en el marco del respeto al derecho a la intimidad y a las declaraciones motivadas de reserva que en todo caso habrán de concretar el interés general al caso concreto; 20) derecho a una ordenación racional y eficaz de los archivos públicos; 21 ) derecho de acceso a la información de interés general, 22) derecho a copia sellada de los documentos que presenten a la Administración pública, 23 ) derecho a ser informado y asesorado en asuntos de interés general $\left.{ }_{i} 24\right)$ derecho a ser tratado con cortesía y cordialidad 25 ) derecho a conocer el responsable de la tramitación del procedimiento administrativo; 26) derecho a conocer el estado de los procedimientos administrativos que les afecten; 27) derecho a ser notificado por escrito o a través de las nuevas tecnologías de las resoluciones que les afecten en el más breve plazo de tiempo posible, que no excederá de los cinco días; 28) derecho a participar en asociaciones o instituciones de usuarios de servicios públicos o de interés general, 29) derecho a actuar en los procedimientos administrativos a través de representante; 30) derecho a exigir el cumplimiento de las responsabilidades del personal al servicio de la Administración pública y de los particulares que cumplan funciones administrativas $; 31$ ) derecho a recibir atención especial y preferente si se trata de personas en situación de discapacidad, niños, niñas, adolescentes, mujeres gestantes o adultos mayores, y en general de personas en estado de indefensión o de debilidad manifiesta". Ibíd., pp. 172-174. 
propuestos en su libro fueron incorporados a la Carta Iberoamericana, respectivamente, en sus capítulos segundo (numerales 2 al 24) y tercero (26 al 46). Como se ve, el documento aprobado por el CLAD aporta grandes avances en lo que concierne al derecho en debate, progresando más allá de la tímida relación de derechos inicialmente propuesta por la Carta de Derechos Fundamentales de la Unión Europea.

\section{CONCLUSIONES}

El derecho fundamental a la buena Administración pública, de la manera como fue originariamente previsto en el artículo 41 de la Carta de Derechos Fundamentales de la Unión Europea en el año 2000, no significó propiamente una novedad en materia de protección de derechos, una vez que las posiciones jurídicas mencionadas en dicho documento ya habían sido reconocidas por la doctrina y jurisprudencia de la Unión Europea.

Sin embargo, tras el desarrollo de la doctrina en torno al tema, actualmente ese derecho busca materializar cambios relevantes en la forma como la Administración pública en todos los Estados ejerce su poder frente a la ciudadanía. Por ello, una de sus principales contribuciones descansa en el énfasis colocado en la centralidad del ciudadano y de los derechos fundamentales a la hora de justificar el ejercicio del poder público.

Aunque los ordenamientos jurídicos internos de los Estados no determinen explícitamente el derecho fundamental a la buena Administración pública, a lo largo del presente artículo ha sido posible verificar como la doctrina y la jurisprudencia en los países iberoamericanos en general y en Brasil en particular han reconocido, aunque muchas veces de manera implícita, la existencia de dicho derecho en sus sistemas jurídicos.

Para interpretar el contenido y alcance del derecho a la buena Administración, es posible utilizar los parámetros básicos establecidos en la Carta de Derechos Fundamentales de la Unión Europea y de la Carta Iberoamericana de Derechos y Deberes del Ciudadano en relación con la Administración pública. Sin embargo, es también necesario tener en cuenta que los enunciados de estos dispositivos internacionales pueden ampliarse conforme las circunstancias específicas que demande cada situación en particular y de acuerdo con lo que se encuentra establecido en cada ordenamiento jurídico nacional.

En este sentido, es fundamental que todas las Administraciones públicas en los diferentes países actualicen sus procesos y procedimientos alrededor de los enunciados del derecho fundamental a la buena Administración pública, con la finalidad de evitar conflictos con la ciudadanía y legitimar la actuación de los poderes públicos, en razón al cumplimiento de los ordenamientos jurídicos internos, los tratados internacionales, la doctrina y la jurisprudencia aplicables. 


\section{BIBLIOGRAFÍA}

\section{DOCTRINA}

Almeida, Fernando Dias Menezes de. "Princípios da Administração Pública e segurança jurídica", en Tratado sobre o princípio da segurança jurídica no Direito Administrativo, Belo Horizonte: Fórum, 2013.

ANDREANI, ANTONIO. Il principio costituzionale di buon andamento della pubblica amministrazione, Padova: CEDAM, 1979.

Bacellar Filho, Romeu Felipe. "A estabilidade do ato administrativo criador de direitos à luz dos princípios da moralidade, da segurança jurídica e da boa-fé", $A \& C$ - Revista de Direito Administrativo \& Constitucional, n. ${ }^{\circ} 40$, Belo Horizonte: Instituto de Direito Romeu Felipe Bacellar, 2010.

Bifulco, Raffaele. "Art. 41. Diritto ad una buona amministrazione", en L'Europa dei diritti: commento alla Carta dei diritti fondamentali dell'Unione Europea, Bologna: Società Editrice Il Mulino, 2001.

Bitencourt Neto, Eurico. "Transformações do Estado e a Administração Pública no século XXI", Revista de Investigações Constitucionais, vol. 4, n. ${ }^{\circ}$ 1, Curitiba: Capes, 2017.

Blanchet, Luiz Alberto y TÂmera Padoin Marques Marin. "A corrupção como violação de direitos humanos e a necessária efetividade da Lei n. ${ }^{\circ} 12.846 / 13^{\prime \prime}, A_{\&} C$ - Revista de Direito Administrativo \& Constitucional, n. ${ }^{\circ} 71$, Belo Horizonte: Instituto de Direito Romeu Felipe Bacellar, 2018.

Buteler, Alfonso. "Los sistemas para el control de la corrupción pública en el orden global", Revista de Direito Econômico e Socioambiental, Curitiba, vol. 8, n. ${ }^{\circ}$ 3, Curitiba: Pontificia Universidad Católica de Paraná, 2017.

Calmes, Sylvia. Du principe de protection de la confiance légitime en droits allemand, communautaire et français, Paris: Dalloz, 2001.

Carmona Garias, Silvia. "Nuevas tendencias en la participación ciudadana en España: ¿socializando la gestión pública o socializando la responsabilidad política?", $\mathrm{A \&} C$ - Revista de Direito Administrativo \& Constitucional, n. ${ }^{\circ} 66$, Belo Horizonte: Instituto de Direito Romeu Felipe Bacellar, 2016.

Castillo Blanco, Federico A. La protección de confianza en el derecho administrativo, Madrid: Marcial Pons, 1998.

Correia, José Manuel Sérvulo. "Os grandes traços do direito administrativo no século XxI", A\&C - Revista de Direito Administrativo \& Constitucional, n. ${ }^{\circ}$ 63, Belo Horizonte: Instituto de Direito Romeu Felipe Bacellar, 2016 
Corvalán, Juan Gustavo. "Los ejes centrales de la división de poderes en el Estado constitucional de derecho", Revista de Investigações Constitucionais, vol. 2, n. ${ }^{\circ}$, Curitiba: Capes, 2015.

Corvalán, Juan Gustavo. "Soberanía y Estado constitucional". A\&C - Revista de Direito Administrativo \& Constitucional, n. ${ }^{\circ}$ 62, Belo Horizonte: Instituto de Direito Romeu Felipe Bacellar, 2015.

Corvalán, Juan Gustavo. "Transformações do 'regime de Direito Administrativo': a propósito do regime exorbitante e das prerrogativas da Administração Pública", $A_{\&} C$ - Revista de Direito Administrativo \& Constitucional, n. ${ }^{\circ}$ 51, Belo Horizonte: Instituto de Direito Romeu Felipe Bacellar, 2013.

Coviello, Pedro. La protección de la confianza del administrado: Derecho argentino y derecho comparado, Buenos Aires: Abeledo Perrot, 2004.

Delpiazzo, Carlos E. "Centralidad del administrado en el actual derecho administrativo: impactos del Estado constitucional de derecho", Revista de Investigações Constitucionais, vol. 1, n. ${ }^{\circ}$ 3, Curitiba: Capes, 2014.

Di Pietro, Maria Sylvia Zanella. "Os princípios da proteção à confiança, da segurança jurídica e da boa-fé na anulação do ato administrativo", en Direito Público Atual: Estudos em bomenagem ao Professor Nelson Figueiredo, Belo Horizonte: Fórum, 2008.

Durán Martínez, Augusto. "Estado constitucional de derecho y servicios públicos", A\&C - Revista de Direito Administrativo \& Constitucional, n. ${ }^{\circ}$ 60, Belo Horizonte: Instituto de Direito Romeu Felipe Bacellar, 2015.

Durán Martínez, Augusto. "La buena administración", Estudios de Derecho Administrativo, n. ${ }^{\circ}$ 1, Montevideo: La Ley, 2010.

Durán Martínez, Augusto. Contencioso administrativo, Montevideo: Fundación de Cultura Universitaria, 2007.

FALZONE, Guido. Il dovere di buona amministrazione, Milan: Giuffrè, 1953.

Fernández Tomás, Antonio. La Carta de Derechos Fundamentales de la Unión Europea, Valencia: Tirant lo Blanch, 2001.

Finger, Ana Cláudia. "O princípio da boa-fé e a supremacia do interesse público - Fundamentos da estabilidade do ato administrativo", en Direito Administrativo e Interesse Público: Estudos em homenagem ao Professor Celso Antônio Bandeira de Mello, Belo Horizonte: Fórum, 2010.

Finger, Julio Cesar. "O direito fundamental à boa administração e o princípio da publicidade administrativa" Interesse Públic, n. ${ }^{\circ}$ 58, Belo Horizonte: Instituto Brasileiro de Altos Estudos de Direito Público, 2009. 
Fortini, Cristiana y Ariane Shermam. "Corrupção: causas, perspectivas e a discussão sobre o princípio do bis in idem", Revista de Investigações Constitucionais, Curitiba, vol. 5, n. ${ }^{\circ}$ 2, Curitiba: Capes, 2018.

Freitas, JuARez. Discricionariedade administrativa e o direito fundamental à boa administração pública, São Paulo: Malheiros, 2007.

Freitas, Rafael Veras De. "O dever de planejamento como corolário ao direito fundamental à boa Administração Pública", Direito Administrativo: estudos em bomenagem a Francisco Mauro Dias, Rio de Janeiro: Lumen Juris, 2009.

Fuentetaja Pastor, Jesús Ángel. "El derecho a la buena administración en la Carta de los derechos fundamentales de la Unión Europea", Revista de Derecho de la Unión Europea, n. ${ }^{\circ}$ 15, Madrid: Colex, 2008.

Gabardo, Emerson. "O princípio da supremacia do interesse público sobre o interesse privado como fundamento do Direito Administrativo Social", Revista de Investigações Constitucionais, vol. 4, n. ${ }^{\circ}$ 2, Curitiba: Capes, 2017.

Galera Rodrigo, Susana. "El derecho a una buena administración", en Comentarios a la Constitución Europea, t. II, Los derechos y libertades, Valencia: Tirant lo Blanch, 2004.

García Luengo, JaVIER. El principio de protección de la confianza en el derecho administrativo, Madrid: Civitas, 2002.

García Roca, Javier. "Originario y derivado en el contenido de la Carta de los Derechos Fundamentales de la Unión Europea: los test de constitucionalidad y convencionalidad", Revista de Estudios Políticos, n. ${ }^{\circ} 119$, Madrid: Centro de Estudios Políticos y Constitucionales, 2003.

González Alonso, Luis N. "Artículo 41: Derecho a una buena administración", en Carta de los Derechos Fundamentales de la Unión Europea: comentario artículo por artículo, Bilbao: Fundación BBVA, 2008.

González PéRez, Jesús. El principio general de la buena fe en el derecho administrativo, 5. a ed., Madrid: Civitas - Thomson Reuters, 2009.

Grando, Felipe Esteves. "O direito fundamental à boa administração pública e seu diálogo com o Direito Tributário", Interesse Público, n. ${ }^{\circ}$ 59, Belo Horizonte: Instituto Brasileiro de Altos Estudos de Direito Público, 2010.

Leal, Rogério Gesta. "A estabilidade do ato administrativo criador de direitos: reflexões para o Brasil", en El acto administrativo como fuente del derecho administrativo en Iberoamérica, Panamá: Congrex, 2009.

Lorenzo de Membiela, Juan B. "La buena administración en la Administración general del Estado", Actualidad Administrativa, n. ${ }^{\circ}$ 4, Madrid: La Ley, 2007. 
Maffini, Rafael. Princípio da proteção substancial da confiança no Direito Administrativo brasileiro, Porto Alegre: Verbo Jurídico, 2006.

Martín-Retortillo Baquer, Lorenzo. "Dos notas sobre la Carta", en La encrucijada constitucional de la Unión Europea, Madrid: Civitas, 2002.

Mello, Celso Antônio Bandeira de. "A estabilidade dos atos administrativos e a segurança jurídica, boa-fé e confiança legítima ante atos estatais", Grandes Temas de Direito Administrativo, São Paulo: Malheiros, 2009.

Mello, Celso Antônio Bandeira De. Curso de Direito Administrativo, 30. a ed., São Paulo: Malheiros, 2013.

Mezzaroba, Orides y Vladmir Oliveira da Silveira. "The principle of the dignity of human person: A reading of the effectiveness of citizenship and human rights through the challenges put forward by globalization", Revista de Investigações Constitucionais, vol. 5, n. ${ }^{\circ}$ 1, Curitiba: Capes, 2018.

Oliveira, Gustavo Henrique Justino de y Julieta Mendes Lopes Vareschini. "Administração pública brasileira e os 20 anos da Constituição de 1988: momento de predomínio das sujeições constitucionais em face do direito fundamental à boa administração pública", Fórum Administrativo, n. ${ }^{\circ}$ 95, Belo Horizonte: ed. Fórum, 2009.

Ospina Garzón, Andrés Fernando. "Instrumentos de la lucha contra la corrupción en Colombia: de la ultima ratio a la ausencia de razón", $A \& C$ - Revista de Direito Administrativo \& Constitucional, ${ }^{\circ}{ }^{\circ}$ 63, Belo Horizonte: Instituto de Direito Romeu Felipe Bacellar, 2016.

Parejo Alfonso, Luciano et al. Manual de derecho administrativo comunitario, Madrid: CEURA, 2000.

Pires, Luís Manuel FonseCa. "Responsabilidade civil do Estado por insuficiência da segurança pública", en Responsabilidade civil do Estado: desafios contemporâneos, São Paulo: Quartier Latin, 2010.

Rodríguez Bereijo, Álvaro. "La Carta de los derechos fundamentales de la Unión Europea y la protección de los derechos humanos", en Unión Europea y derechos fundamentales en perspectiva constitucional, Madrid: Dykinson, 2004.

Rodríguez-Arana Muñoz, Jaime. "Dimensiones del Estado social y derechos fundamentales sociales", Revista de Investigações Constitucionais, vol. 2, n. ${ }^{\circ}$ 2, Curitiba: Capes, 2015.

RodríGueZ-Arana MuÑoz, JaImE. "El derecho administrativo ante la crisis (El derecho administrativo social)", A\&C - Revista de Direito Administrativo \& Constitucional, n. ${ }^{\circ} 60$, Belo Horizonte: Instituto de Direito Romeu Felipe Bacellar, 2015. 
Rodríguez-Arana Muñoz, Jaime. "El derecho fundamental a la buena administración en la Constitución española y en la Unión Europea", $A \& C$ - Revista de Direito Administrativo \& Constitucional, n. ${ }^{\circ}$ 40, Belo Horizonte: Instituto de Direito Romeu Felipe Bacellar, 2010.

Rodríguez-Arana Muñoz, Jaime. "El derecho fundamental al buen gobierno y a la buena administración de instituciones públicas", Revista de Estudios Locales (CUNAL), n. ${ }^{\circ}$ 100, Madrid: Thomson-Aranzadi, 2007.

Rodríguez-Arana Muñoz, Jaime. "La participación en el Estado social y democrático de Derecho", $A \& C$ - Revista de Direito Administrativo \& Constitucional, n. ${ }^{\circ} 48$, Belo Horizonte: Instituto de Direito Romeu Felipe Bacellar, 2012.

Rodríguez-Arana Muñoz, Jaime. "Los principios de seguridad jurídica, buena fe y confianza legítima", en Tratado sobre o princípio da segurança jurídica no Direito Administrativo, Belo Horizonte: Fórum, 2013.

Rodríguez-Arana Muñoz, Jaime. "Sobre el derecho fundamental a la buena administración y la posición jurídica del ciudadano", $A \& C$ - Revista de Direito Administrativo \& Constitucional, n. ${ }^{\circ} 47$, Belo Horizonte: Instituto de Direito Romeu Felipe Bacellar, 2012.

Rodríguez-Arana Muñoz, Jaime. Direito fundamental à boa Administração Pública, Belo Horizonte: Fórum, 2012.

Ruocco, Graciela. "La 'buena administración' y el 'interés general'", A\&C - Revista de Direito Administrativo \& Constitucional, n. ${ }^{\circ}$ 49, Belo Horizonte: Instituto de Direito Romeu Felipe Bacellar, 2012.

Salgado, Eneida Desiree. "Essay on the constitutional promises of democracy and

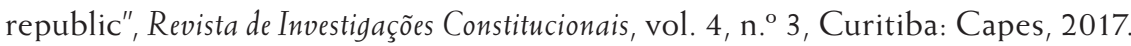

Sarlet, Ingo Wolfgang. A Administração Pública e os direitos fundamentais. Clase impartida em la Escola da Magistratura do Tribunal Regional Federal da 4. ${ }^{\text {a }}$ Região (transcripción). p. 2. Disponible en línea: http://www2.trf4.jus.br/trf4/upload/ arquivos/emagis_atividades/ingowolfgangsarlet.pdf. [Consultado el 5 de agosto de 2018].

SARLET, Ingo WolfGang. A eficácia dos direitos fundamentais: uma teoria geral dos direitos fundamentais na perspectiva constitucional, 10. ${ }^{\mathrm{a}}$ ed., Porto Alegre: Livraria do Advogado, 2010.

Schier, Adriana da Costa Ricardo y Juliane Andrea de Mendes Hey Melo. "O direito à participação popular como expressão do Estado Social e Democrático de Direito", A\&C - Revista de Direito Administrativo \& Constitucional, n. ${ }^{\circ} 69$, Belo Horizonte: Instituto de Direito Romeu Felipe Bacellar, 2017.

SChOnberG, Soren J. Legitimate expectations in administrative law, Oxford: Oxford 2000. 
Silva, Almiro do Couto. "O princípio da segurança jurídica (proteção à confiança) no direito público brasileiro e o direito da administração pública de anular seus próprios atos administrativos: o prazo decadencial do art. 54 da lei do processo administrativo da União (Lei n. ${ }^{\circ}$ 9784/99)", Revista Brasileira de Direito Público, n. ${ }^{\circ} 6$, Belo Horizonte: Forum, 2004.

SÖDERMAn, JACOB. "El derecho fundamental a la buena administración", Gaceta Jurídica de la Unión Europea y de la Competencia, n. ${ }^{\circ}$ 214, Madrid: EINSA Multimedia, 2001.

TOMÁs MaleÉN, BeATRIZ. El derecho fundamental a una buena administración, Madrid: INAP, 2004.

VAlim, Rafael. O princípio da segurança jurídica no Direito Administrativo brasileiro, São Paulo: Malheiros, 2010.

Valle, Vanice Regina LíRIo do. Direito fundamental à boa administração e governança, Belo Horizonte: Fórum, 2011.

Zancaner, Weida. Da Convalidação e da Invalidação dos Atos Administrativos, 3. ${ }^{a}$ ed., São Paulo: Malheiros, 2008.

\section{JURISPRUDENCIA}

BrasiL, Superior Tribunal de Justiça, Recurso Especial n. ${ }^{\circ}$ 1139486/DF, Relator Min. Humberto Martin, Segunda Turma, Julgado em 24.11.2009. DJe 07.12.2009.

BrasiL, Tribunal Regional Federal da 4. ${ }^{a}$ Região, Agravo de Instrumento n. ${ }^{\circ} 5017280$ 90.2013.404.0000, Terceira Turma, Relator Nicolau Konkel Júnior. D.E. 05.08.2013.

Brasil, Tribunal Regional Federal da 4. ${ }^{a}$ Região, Apelação Cível n. ${ }^{\circ} 5013872$. 90.2011.404.7201, Terceira Turma, Relatora Maria Lúcia Luz Leiria. D.E. 25.11.2012.

Brasil, Tribunal Regional Federal da 4. ${ }^{a}$ Região, Apelação Cível n. ${ }^{\circ} 5039808$ 95.2012.404.7100, Terceira Turma, Relator Carlos Eduardo Thompson Flores Lenz. D.E. 14.06.2013.

BRASIL, Tribunal Regional Federal da $4^{a}$ Região, Apelação e Reexame Necessário n. ${ }^{\circ}$ 5025299-96.2011.404.7100, Sexta Turma. Relator p/ Acórdão Celso Kipper. D.E. 16.09.2013.

\section{DOCUMENTOS, ESTUDIOS E INFORMES}

La Administración al Día. "El catedrático Rodríguez-Arana redactará la Carta de Derechos Ciudadanos de Iberoamérica", Madrid: Instituto Nacional de Administración Pública, 2013. Disponible en línea http://laadministracionaldia.inap.es/noticia. asp?id=1500246. [Consultado el 5 de agosto de 2018]. 
Centro latinoamericano de Administración para el Desarrollo. Carta Iberoamericana de los Derechos y Deberes del Ciudadano en Relación con la Administración Pública, Caracas, 2013. Disponible en línea: http://www.clad.org/documentos/ declaraciones/Carta\%20Iberoamericana\%20de\%20los\%20deberes\%20y\%20 derechos\%20-\%20documento\%20aprobado.pdf/view. [Consultado el 5 de agosto de 2018]. 